DOI: https://doi.org/10.24127/ajpm.v8i3.2445

\title{
PENGGUNAAN MEDIA GAME KAHOOT UNTUK MENINGKATKAN HASIL DAN MINAT BELAJAR MATEMATIKA
}

\author{
Sri Wigati \\ SMA Negeri 15 Semarang \\ E-mail: $\quad$ dra.wigati@gmail.com \\ Received 30 October 2019; Received in revised form 8 December 2019; Accepted 28 December 2019
}

\begin{abstract}
Abstrak
Penelitian ini dilatarbelakangi oleh dunia pendidikan yang membutuhkan inovasi media pembelajaran agar siswa tidak merasa bosan pada saat proses belajar mengajar. Tujuan penelitian ini yaitu : a) mengetahui peningkatan hasil belajar siswa; b) mengetahui keterampilan proses siswa; c) mengetahui minat belajar. Jenis penelitian ini adalah Penelitian Tindakan Kelas (PTK). Pengumpulan data dengan menggunakan metode tes, observasi, dan angket. Hasil penelitian ini yaitu: a) terdapat peningkatan rata rata hasil belajar 87 pada siklus I dan siklus II sebesar 92; b) terdapat peningkatan keterampilan proses siswa sebesar 83 pada siklus I dan siklus II sebesar 92; c) terdapat peningkatan minat belajar sebesar $82 \%$ pada siklus I dan $93 \%$ pada siklus II.
\end{abstract}

Kata kunci: Hasil belajar; Kahoot; minat belajar.

\begin{abstract}
This research is motivated by the world of education which requires innovative learning media so that students do not feel bored during the teaching and learning process. The purposes of this study are: a) find out the improvement of student learning outcomes; b) know the student's process skills; c) know your interest in learning. This type of research is Classroom Action Research (CAR). Data collection used the test, observation, and questionnaire methods. The results of this study are: a) there is an increase in the average learning outcomes 87 in cycle I and cycle II of 92; b) there was an increase in students' process skills by 83 in cycle I and cycle II by 92; c) there was an increase in interest in learning by $82 \%$ in cycle I and $93 \%$ in cycle II.
\end{abstract}

Keywords: Learning outcomes; Kahoot; interest to learn

\section{PENDAHULUAN}

Penggunaan teknologi informasi di zaman globalisasi dan era digital ini tidak dapat dikesampingkan dan menjadi suatu kebutuhan yang sangat vital oleh masyarakat, sehingga perkembangan teknologi informasi sangat berkembang pesat dan maju serta mendapat minat yang sangat baik oleh masyarakat. Perkembangan teknologi informasi yang ini sangat berpengaruh dalam berbagai kehidupan Salah satunya berdampak positif dalam bidang pendidikan (Basori, 2013; Herlambang \& Hidayat, 2016) yang mengakibatkan mutu pendidikan meningkat (Nasrullah, Ende, \& Suryadi, 2017).

Berdasarkan data dari Badan Pusat Statistik (BPS) yang menyebutkan bahwa persentase penduduk yang mengakses internet pada tahun 2013 sekitar 14,90\% dan pada tahun 2017 meningkat menjadi $32,34 \%$. Internet sangat penting untuk digunakan dalam berbagai bidang di kehidupan sehari hari. Salah satu yang menjadi kebutuhan masyarakat yang lainnya adalah kepemilikan smartphone, Maraknya pemuda atau para siswa yang menggunakan smartphone menjadi hal yang sangat dikhawatirkan 
oleh guru dan kepala sekolah. Hal ini dikarenakan penggunaan smartphone dikhawatirkan menimbulkan dampak negatif dalam proses pembelajaran antara lain : a) jika siswa menggunakan smartphone pada saat proses pembelajaran akan mengganggu konsentrasi siswa dalam belajar; dan b) adanya jejarng sosial mengakibatkan mengarah pada pergaulan yang kurang baik atau bahkan pergaulan bebas.

Penggunaan smartphone dan internet yang seimbang dan dimanfaatkan dengan baik khusunya pada dunia pendidikan, hal ini akan membawa bidang pendidikan untuk maju dan berkembang seiring dengan perkembangannya teknologi informasi dan komunikasi. Maka dari itu proses pembelajaran di sekolah tidak terlepas dari peran teknologi informasi. Misal kegiatan guru dan siswa yang banyak kegiatannya menggunakan media komputer dan internet di sekolah (Maghfiroh, Kirom, \& Munif, 2018).

Analisis hasil belajar siswa kelas $\mathrm{X}$ materi pertidaksamaan rasional dan irasional satu variabel pada tahun 2018/2019 menunjukkan bahwa rata rata hasil belajar yang diperoleh siswa sebesar 68 dengan persentase hanya $30 \%$ saja. Hal tersebut menunjukkan adanya permasalahan dalam proses pembelajaran. Berdasarkan observasi yang dilakukan, permasalahan permasalahan tersebut disebabkan beberapa faktor antara lain: a) matematika bagi sebagian siswa dianggap sebagai pelajaran yang sulit dan enggan untuk mereka pelajari; b) kejenuhan siswa dalam proses pembelajaran dikarenakan guru yang menggunakan media pembelajaran yang kurang menarik dan monoton; c) pemanfaatan teknologi yang salah dikarenakan pada saat proses pembelajaran siswa menggunakan smartphone baik bermain game ataupun bermain sosial media; d) keterampilan dalam pembelajaran yang kurang dikarenakan pembelajaran yang berpusat pada guru; e) minat belajar dalam penggunaan media pembelajaran yang digunakan kurang.

Penerapan teknologi informasi bisa dimanfaatkan sebagai media pembelajaran dan juga mampu memberikan motivasi kepada siswa untuk aktif dalam kegiatan belajar (Dharmawati, 2017; Hikmawan \& Sarino, 2018), sehingga proses pembelajaran berpusat pada siswa. Hal ini dibuktikan hasil penelitian Nelvi, Fachruddin, \& Rusdi (2017) yang menyatakan bahwa siswa lebih aktif ketika proses pembelajaran beralih tidak berpusat kepada guru. Salah satu media pembelajaran yang bisa diterapkan yaitu media pembelajaran game edukasi Kahoot. Game edukasi Kahoot memiliki keunggulan antara lain soal - soal yang disajikan dalam Game edukasi Kahoot memiliki alokasi waktu yang terbatas, karena dengan adanya keterbatasan waktu siswa dilatih untuk berpikir cepat dan tepat dalam menyelesaikan soal dengan media Kahoot. Keunggulan lain dari game edukasi Kahoot yaitu jawaban dari soal yang diberikan akan diwakili oleh gambar dan warna serta tampilan pada perangkat guru dan perangkat siswa akan otomatis berganti menyesuaikan dengan nomor soal yang ditampilkan.

Pada game edukasi kahoot terdapat dua cara bermain yaitu Classic dan Team Mode. Bermain cara classic berarti siswa bermain secara individu sedangkan bermain cara team mode berarti siswa bermain secara berkelompok. Jika bermain cara classic akan muncul satu nama siswa sedangkan jika bermain cara team 
mode akan muncul nama - nama siswa dalam satu kelompok. Classic dan team mode merupakan salah satu solusi yang digunakan dalam penelitian ini, karena berdasarkan hasil observasi di kelas, peneliti melihat masih ada siswa yang bekerja secara individu meskipun guru sudah membentuk siswa dalam kelompok dan peneliti melihat siswa yang suka bermain sendiri atau individu. Selain itu, dengan memanfaatkan teknologi untuk siswa diharapkan dunia pendidikan mampu bersaing dengan bangsa lain dan pendidikan di Indoensia diharapkan mampu menciptakan keluaran yang pandai teknologi.

Penelitian yang dilakukan oleh Lime (2018) menunjukkan bahwa pemanfaatan media kahoot pada proses pembelajaran sangat baik; Kerjasama siswa yang telah diverifikasi dengan hasil wawancara didapatkan hasil bahwa kerjasama siswa termasuk dalam kategori sangat baik. 3) Persentase hasil belajar ketuntasan belajar termasuk dalam kategori sangat baik.

Penelitian yang dilakukan oleh Yogga \& Tetep (2018) Berdasarkan penelitian tersebut ditunjukkan bahwa ada pengaruh yang signifikan antara penggunaan aplikasi Kahoot dan peningkatan minat belajar. Penelitian lain yang dilakukan oleh Khabidin (2019) menyatakan bahwa terdapat perbedaan yang signifikan, dan dapat disimpulkan bahwa ada perbedaan antara efektifitas penerapan kahoot dalam mengkondisikan kelas dalam mata pelajaran pendidikan agama islam di SMP N 1 Pagetan Kabupaten Banjarnegara.

Tujuan penelitian ini adalah a) Menentukan peningkatan hasil belajar siswa dengan implementasi media game edukasi Kahoot; b) Mengetahui peningkatan keterampilan proses dengan implementasi media game edukasi Kahoot; c) Mengetahui minat siswa terhadap implementasi media game edukasi Kahoot dalam pembelajaran materi pertidaksamaan rasional dan irasional satu variabel.

\section{METODE PENELITIAN}

Penelitian ini adalah Penelitian Tindakan Kelas (PTK) yang dilaksanakan untuk mengetahui hasil belajar, keterampilan proses siswa, dan minat belajar yang mengimplementasikan game edukasi Kahoot. Penelitian ini menggunakan model Kemmis dan Mac Tanggart dengan empat tahapan yaitu perencanaan, pelaksanaan tindakan, observasi atau pengamatan, dan refleksi. Penelitian ini dilaksanakan di SMA Negeri 15 Semarang pada semester I tahun pelajaran 2018/2019. Subjek penelitian ini adalah siswa kelas $\mathrm{X}$ IPA 7 yang berjumlah 36 siswa yang terdiri dari 16 siswa laki - laki dan 20 siswa perempuan. Penelitian ini dirancang dalam 2 siklus yang setiap siklusnya terdiri dari empat tahapan yaitu : 1) perencanaan; 2) pelaksanaan tindakan; 3) observasi atau pengamatan; 4) refleksi. Setiap siklus terdiri dari tiga pertemuan tatap muka. Setiap siklus dilaksanakan sesuai dengan perubahan yang ingin dicapai seperti apa yang telah didesain.

Teknik pengumpulan data dalam penelitian ini yaitu : a) Tes, digunakan untuk memperoleh tes data hasil belajar siswa. Data tes ini diambil pada setiap siklus yang terdiri dari dua siklus, sehingga tiap siklus diperoleh data pre test dan post test mengenai materi pertidaksamaan rasional dan irasional satu variabel; b) Observasi, digunakan untuk memperoleh data mengenai keterampilan proses siswa dalam 
DOI: https://doi.org/10.24127/ajpm.v8i3.2445

proses pembelajaran yang mengimplementasikan media game edukasi Kahoot, dalam observasi ini juga diambil dalam tiap siklusnya mengenai keterampilan proses. c) Angket, digunakan untuk memperoleh data mengenai minat belajar siswa setelah pelaksanaan proses pembelajaran pada tiap siklusnya. Analisis data diawali dengan uji validitas, taraf kesukaran, daya beda, dan reliabilitas pada soal pre test dan post test, sedangkan uji instrumen angket dilaksanakan uji validitas dan reliabilitas.

\section{HASIL PENELITIAN DAN PEMBAHASAN}

Hasil penelitian yang dilakukan pada siklus I dan siklus II di kelas X IPA7 SMA Negeri 15 Semarang menunjukkan adanya peningkatan hasil belajar matematika dalam implementasi media game edukasi Kahoot. Peningkatan hasil belajar ini dapat dilihat pada Gambar 1.

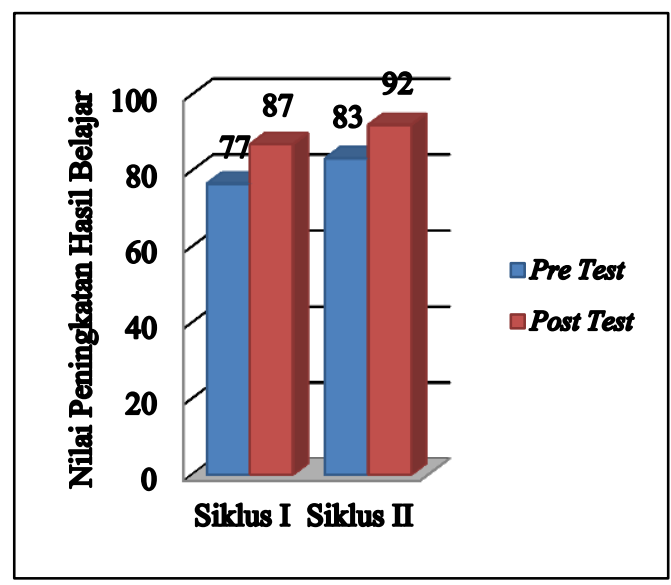

Gambar 1. Peningkatan hasil belajar siklus I dan siklus II

Berdasarkan hasil belajar pada Gambar 1 dapat dilihat bahwa terdapat peningkatan pada tiap siklusnya antara pre test dan post test hasil belajar materi pertidaksamaan rasional dan irasional satu variabel. Terdapat pula peningkatan rata-rata post test hasil belajar antara siklus I dan siklus II. Pada siklus I diperoleh rata-rata hasil belajar sebesar 87 yang nilainnya kurang dari rata-rata hasil belajar pada siklus II yang sebesar 92. Langkah selanjutnya dari analisis hasil belajar post test juga terdapat peningkatan jumlah siswa yang tuntas dalam setiap siklusnya.

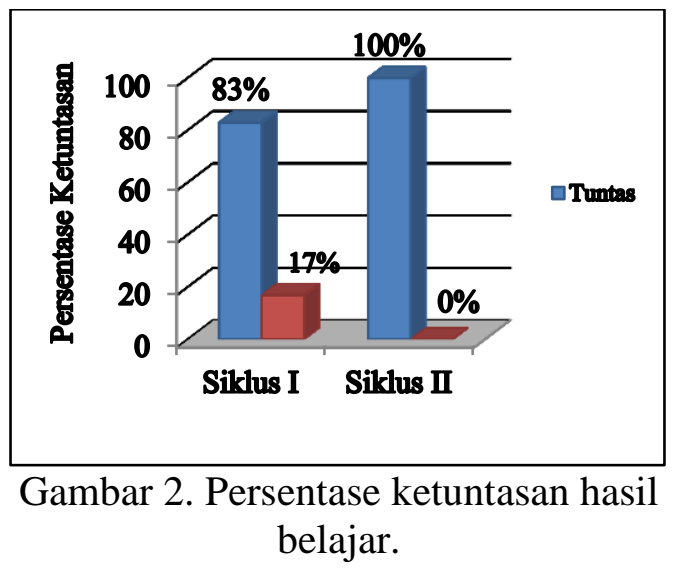

Berdasarkan persentase ketuntasan hasil belajar pada Gambar 2 dapat disimpulkan bahwa setiap siklus terdapat peningkatan yang signifikan pada jumlah siswa yang tuntas, dimana pada siklus I jumlah siswa yang tuntas sebanyak $83 \%$ dari 36 siswa dan siklus II sebanyak $100 \%$ siswa yang tuntas dari 36 siswa.

Pada hasil analisis keterampilan proses siswa dalam pelaksanaan proses pembelajaran diperoleh hasil peningkatan pada Gambar 3. 
DOI: https://doi.org/10.24127/ajpm.v8i3.2445

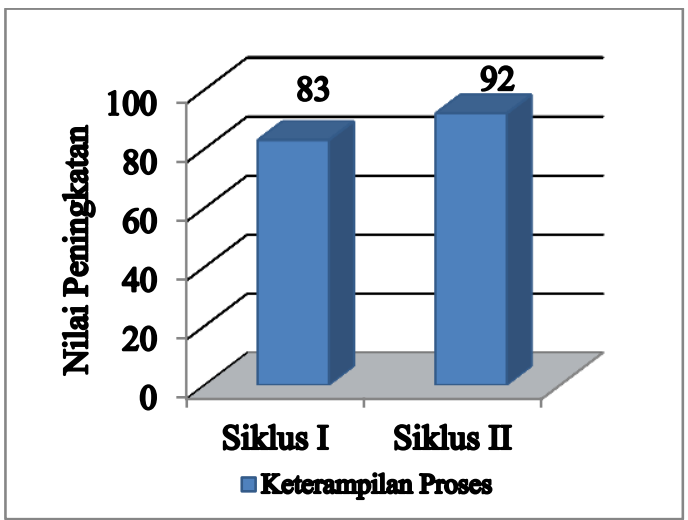

Gambar 3. Peningkatan keterampilan proses.

Gambar 3 menunjukkan adanya peningkatan yang signifikan pada hasil observasi keterampilan proses siswa dalam proses pembelajaran yang mengimplementasikan media game Kahoot sebagai media pembelajaran dalam evaluasi materi pertidaksamaan rasional dan irasional satu variabel. Pada siklus I diperoleh rata-rata keterampilan proses sebesar 83, sedangkan pada siklus II diperoleh rata-rata keterampilan proses sebesar 92. Hal ini menunjukkan bahwa, selain hasil belajar ternyata penggunaan game Kahoot juga menimbulkan peningkatan dalam keterampilan proses siswa ketika pelaksanaan evaluasi pembelajaran materi pertidaksamaan rasional dan irasional satu variabel.

Penggunaan game Kahoot dalam proses pembelajaran tersebut ternyata juga menimbulkan minat belajar dari siswa. Hal itu dapat dilihat dari siswa senang dan bersemangat dalam proses pembelajaran pada saat penerapan game Kahoot. Hal ini didasari karena belum ada guru yang menerapkan game Kahoot dalam proses pembelajaran.

Berdasarkan hasil penelitian diperoleh bahwa terdapat peningkatan yang signifikan dari minat belajar yang diberikan siswa dalam proses pembelajaran pada tiap siklusnya. Pada siklus I diperoleh minat belajar sebesar $82 \%$ dan siklus II sebesar 93\%. Grafik persentase minat belajar siswa ditunjukkan pada Gambar 4.

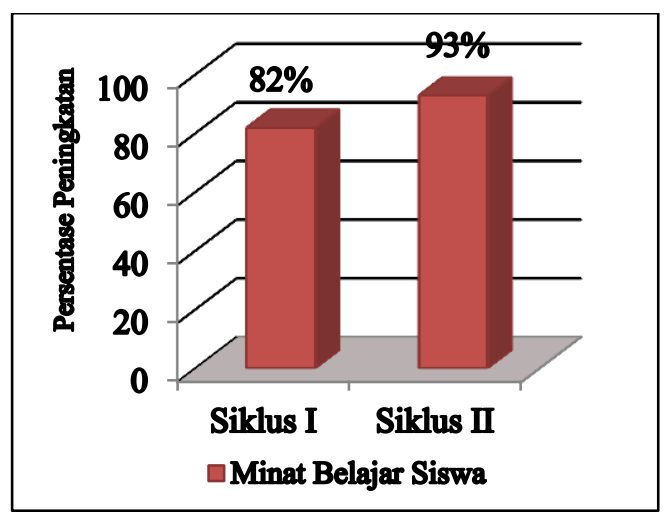

Gambar 4. Persentase minat belajar siswa.

Analisis data yang diperoleh selama proses penelitian dapat ditarik kesimpulan bahwa dari setiap variabel yang diukur yaitu hasil belajar, keterampilan proses, dan minat belajar siswa setelah implementasi game edukasi Kahoot terdapat peningkatan yang signifikan dalam setiap siklusnya. Hasil peningkatan tersebut disebabkan adanya beberapa faktor dalam proses pembelajaran antara lain dengan adanya penggunaan game edukasi Kahoot. Penggunaan game Kahoot tersebut tentunya dapat membantu siswa dalam menyelesaikan masalah terkait evaluasi materi pertidaksamaan rasional dan irasional satu variabel.

Pada materi pertidaksamaan rasional dan irasional satu variabel kesulitan yang dialami siswa adalah menghitung nilai himpunan penyelesaian. Namun dengan menggunakan game edukasi Kahoot siswa dapat dengan mudah menghitung nilai himpunan penyelesaiannya. Adanya kemudahan dalam menyelesaikan permasalahan pertidaksamaan rasional dan irasional satu variabel yang dibantu dengan 
Kahoot berdampak pada peningkatan hasil belajar. Selain itu juga banyak siswa yang tuntas dalam materi pertidaksamaan rasional dan irasional satu variabel. Hal tersebut seperti disimpulkan dalam penelitian Ningrum (2018) yang mengatakan bahwa ketuntasan belajar siswa kelompok eksperimen menggunakan media kahoot pada saat post test sebesar $88 \%$ lebih tinggi daripada kelompok $79,8 \%$.

Berdasarkan hasil pada Gambar 1 terdapat peningkatan pada tiap siklusnya antara pre test dan post test hasil belajar materi pertidaksamaan rasional dan irasional satu variabel. Selain hasil belajar ternyata penggunaan Kahoot juga menimbulkan peningkatan dalam keterampilan proses ketika siswa menyelesaikan permasalahan terkait pertidaksamaan rasional dan irasional satu variabel. Meskipun Kahoot dengan mudah dapat menyelesaikan permasalahan namun tetap diperlukan konsep dasar dalam matematika itu sendiri.

Dampak penggunaan Kahoot dalam proses pembelajaran tersebut dapat menimbulkan minat belajar siswa. Dimana siswa senang dengan dikenalkannya game edukasi Kahoot. Selain itu, Kahoot yang digunakan juga dapat dipakai di hp android masing masing. Penggunaan game edukasi Kahoot dalam evaluasi pembelajaran dilaksanakan agar evaluasi lebih menarik dan tidak monoton sehingga siswa akan lebih semangat dan termotivasi untuk mengerjakan evaluasi pembelajaran pertidaksamaan rasional dan irasional satu variabel. Permainan game edukasi Kahoot ini juga dimaksudkan untuk belajar sambil bermain, sehingga diharapkan hasil belajar siswa dapat meningkat dengan bantuan game Kahoot. Game Kahoot juga bisa mengkondisikan kelas dengan efektif, hal ini dibuktikan dengan penelitian yang dilakukan oleh Khabidin (2019) yang dapat disimpulkan bahwa ada perbedaan dalam mengkondisikan kelas dengan game Kahoot.

Berdasarkan pembahasan di atas, dapat disimpulkan bahwa penggunaan teknologi dalam pembelajaran dapat membantu siswa untuk terampil dalam menyelesaikan permasalahan ataupun dalam menentukan konsep serta melatih konsep yang dimiliki. Hal ini seperti yang dikemukakan oleh Muhtadi (2015) pemanfaatan teknologi informasi dalam pendidikan mempunyai arti penting terutama dalam upaya pemerataan pendidikan, peningkatan kualitas pendidikan, dan peningkatan efektifitas pendidikan.

\section{KESIMPULAN DAN SARAN}

Berdasarkan hasil penelitian dan pembahasan yang diuraikan di atas, diperoleh kesimpulan sebagai berikut: 1) terdapat peningkatan hasil belajar siswa dari siklus I sebesar 87 dan siklus II sebesar 92; 2) terdapat peningkatan keterampilan proses siswa dari siklus I sebesar 83 dan siklus II sebesar 92; 3) terdapat peningkatan minat belajar siswa sebesar $82 \%$ pada siklus I dan siklus II sebesar 93\%.

Saran yang diberikan dari hasil penelitian ini adalah 1) sebagai pendidik di era modern hendaknya mampu menguasai semua kompetensi yang wajib dimiliki pendidik dan mampu menguasai teknologi dalam pembelajaran; 2) pemanfaatan teknologi khususnya game edukasi Kahoot pada proses pembelajaran dapat dilakukan pada materi lain sebagai media pembelajaran dalam evaluasi pembelajaran; 3) perlu adanya simulasi dalam penggunaan game edukasi 
Kahoot terlebih dahulu sehingga pada siklus I akan diperoleh hasil yang maksimal; 4) pendidik hendaknya menerapkan game edukasi Kahoot sebagai bagian dari teknologi pendidikan untuk menciptakan suasana pembelajaran yang menyenangkan sehingga siswa akan termotivasi.

\section{DAFTAR PUSTAKA}

Basori. (2013). Pemanfaatan Social Learning Network"EDMODO" dalam Membantu Perkuliahan Teori Bodi Otomotif di Prodi PTM JPTK FKIP UNS. JIPTEK, 4(2), 99-105.

BPS. (2018). Statistika Telekomunikasi Indonesia 2017. Jakarta: Badan Pusat Statistik.

Dharmawati. (2017). Penggunaan Media e-Learning Berbasis Edmodo Dalam Pembelajaran English for Business. QUERY: Jurnal Sistem Informasi, 1(1), 43-49.

Herlambang, A.D. \& Hidayat, W.N. (2016). Edmodo untuk Meningkatkan Kualitas Perencanaan Proyek dan Efektivitas Pembelajaran di Lingkungan Pembelajaran yang Bersifat Asinkron. Jurnal Teknologi Informasi dan Ilmu Komputer (JTIIK), 3(2), 1-8.

Hikmawan, T., \& Sarino, A. (2018). Pembelajaran Berbasis Media Pembelajaran Edmodo Terhadap Motivasi Belajar Siswa Sekolah Menengah Kejuruan. Jurnal Pendidikan Manajemen Perkantoran, 1(2), 78-85.

Khabidin. (2019). Efektifitas Penerapan Aplikasi Kahoot Dalam Mengkondisikan Kelas Pada Mata Pelajaran Pendidikan Agama Islam di
SMP N 1 Pagentan Kabupaten Banjarnegara. Skripsi. Retrieved from https://dspace.uii.ac.id/handle/1 23456789/14126

Lime. (2018). Pemanfaatan Media Kahoot Pada Proses Pembelajaran Model Kooperatif Tipe STAD Ditinjau dari Kerjasama dan Hasil Belajar Siswa Kelas VIII-I SMP Negeri 5 Yogyakarta Tahun Ajaran 2017/2018. Skripsi. Retrieved from http://repository.usd.ac.id/3107 8/2/141414034_full.pdf

Maghfiroh, N. W., Kirom, A., \& Munif. (2018). Pengaruh Penerapan Media Edmodo Terhadap Hasil Belajar Pendidikan Agama Islam di SMK Anwarul Maliki Sukorejo Pasuruan. Al Ghazwah, 2(2), 207-226.

Muhtadi, A. (2015). Pemanfaatan Teknologi Informasi untuk Meningkatkan Kualitas dan Efektifitas Pendidikan. Jurnal Dinamika Pendidikan, 8(2), 205-214.

Nasrullah, Ende, \& Suryadi. (2017). Efektivitas Penggunaan Media Edmodo pada Pembelajaran Matematika Ekonomi Terhadap Komunukasi Matematis. SYMMETRY: Pasundan Journal of Research on Mathematics Learning and Education, 2(1), 1-10.

Nelvi, N. F., Fachruddin, \& Rusdi. (2017). Peningkatan Aktivitas Belajar Matematika Siswa Kelas VII MTSN 1 Kota Bengkulu dengan Model Pembelajaran Talking Stick. Jurnal Penelitian Pembelajaran Sekolah (JP2MS). 1(1): 41-46. 
DOI: https://doi.org/10.24127/ajpm.v8i3.2445

Ningrum, G. D. K. (2018). Studi Penerapan Media Kuis Interaktif Berbasis Game Edukasi Kahoot! Terhadap Hasil Belajar Mahasiswa. Vox Edukasi: Jurnal Ilmiah Ilmu Pendidikan. 9(1), 22-27.

Yogga, M. M., \& Tetep. (2018). Implementation Of Kahoot Application To Improving Of Interest of Civic Education Learning (Experimental Research In Class XI Of SMA Negeri 1 Garut). Journal Civics \& Social Studies. 2(1), 75-92. 